\title{
PHIL ZUCKERMAN
}

\section{Contrasting irreligious orientations Atheism and secularity in the USA and Scandinavia}

\begin{abstract}
A theism and secularity are not static, fixed orientations. Rather, atheism and secularity are contoured, malleable, and deeply shaped by cultural and social forces. A clear example of the degree to which atheism and secularity can be lived and expressed quite differently in different socio-cultural locations is revealed by comparing and contrasting the ways in which they are manifested in the United States and Scandinavia.
\end{abstract}

\section{Introduction}

In his groundbreaking book Toward a Sociology of Irreligion (1971), Colin Campbell spoke of a 'range of irreligiousness' (p. 35), thereby alerting scholars to the mistake of speculating or hypothesising about a fixed, ideal, or 'pure' type of secularity. Echoing this sentiment, Paul Pruyser (1974: 195) has acknowledged a 'complexity of unbelief', suggesting that unbelief may be 'as diversified as religious belief'. Indeed, both atheism and irreligion come in a fairly wide variety of shapes, sizes, and textures. For example, a nonreligious individual can be overtly hostile to religion, and actively seek its demise. In contrast, another nonreligious individual can simply be indifferent to religion, even oblivious. In yet another instance, atheism can be something one chooses for very clear reasons, maintains with pride, and defends with vigilance or atheism can be akin to a passive default position, an orientation that exists mundanely, uncritically, even unknowingly. And beyond these various types or manifestations of atheisms/secularities briefly described for the sake of illustration, we can easily imagine many other such idiosyncratic irreligious orientations, with their own important nuances. Some have recently attempted to start to chart this typological diversity (Pasquale 2006). For example, Barry Kosmin (2007) has made a distinction between 'soft' and 'hard' seculars. Chaeyoon Lim et al. (2010) have added 'liminals' - those 'betwixt and between' religiosity and secularity - as a distinctive type, rather similar to those people exhibiting the 'fuzzy fidelity' discussed by David Voas (2008), and further elaborated by Ingrid Storm (2009). Peter Lüchau (2010) distinguishes between 'atheists' and the 'a-religious' - the former actively care about religion and seek to curb its influence, while the latter simply do not care about religion one way or another. And finally, N. J. Demerath (2001) and Phil Zuckerman (2008) have discussed the non-believing, 'culturally religious' those who identify with a religion, even while simultaneously rejecting its actual creeds and supernatural assumptions, an orientation very similar to what Ina Rosen (2009) calls 'religion-as-heritage'. In short, the diversity of secular orientations is significant, and this significance is becoming more and more recognised (Pasquale, Galen \& Zuckerman 2013).

Given that there exist different forms or types of secular orientations, the question arises: what might account for these differences? Surely, on some level, it is a psychological matter, relating to individual personality types, emotional dispositions, innate neurological wiring, and so on. And it also surely has something to do with a given individual's family-life circumstances, personal experiences with religion, and so on. But beyond these psychological, individualistic, or familial factors influencing the form of people's secularity or atheism, there undoubtedly exists the social or cultural level of influence. That is to say, the culture/society in which a person lives will greatly shape his or her secular orientation. As Colin Campbell (1971: 29) succinctly argued, 'Irreligion can only be specified within a given social and cultural context.'

For a clear example that serves to illustrate the above assertion, I will contrast contemporary non-re- 
ligious Americans with contemporary non-religious Danes and Swedes, showing that most non-religious people in America exhibit certain traits and orientations markedly different from most non-religious people in Scandinavia. I will highlight these three key differences:

- Different experiences of - and feelings about their apostasy (rejection of religion).

- Different opinions concerning religion.

- Different personal beliefs and articulations concerning the non-existence of God.

\section{Methodology and samples}

The observations offered in this paper are based upon two years of fieldwork in Aarhus, Denmark (2005-6, 2010-11), as well in-depth interviews with 149 Danes and Swedes, and 90 in-depth interviews with Americans. In both cases, interviewees were obtained by employing a nonjudgmental, purposive, snowball sampling method, typical for such qualitative research.

Of the 149 Scandinavian interviewees, about two thirds self-identified as non-religious, while the remaining third were religious, of varying degrees and types. Of the total interviewed, 75 were men and 74 were women. 103 were Danish, 39 were Swedish, and 7 were immigrants to Denmark from Chile, Iran, or Turkey. In terms of the education levels of my informants, approximately 34 per cent had completed the equivalent of a university degree, approximately 15 per cent had completed some university courses but never achieved a degree, or were currently enrolled at a college or university, approximately 11 per cent had completed the equivalent of a high school education, approximately 11 per cent had completed some sort of specific professional training (such as how to be a social worker, businessman, preschool teacher, etc.), approximately 15 per cent had completed some form of specific vocational training (such as how to be a tool maker, photographer, nurse, physical therapist, etc.), and approximately 14 per cent had completed somewhere between the 6th and 9th grade. Out of the 149 informants, approximately 23 per cent had been raised in small towns (of populations less than 5,000), approximately 41 per cent had been raised in one of Denmark or Sweden's three largest cities, and approximately 33 per cent had been raised in medium-sized towns (larger than 5,000 people, but not one of the 3 largest cities in Denmark or Sweden). Concerning age, 3 per cent of my informants were between the ages of 15-19, 21 per cent were between 20-29, 25 per cent were between 30-39, 17 per cent were between $40-49,15$ per cent were between $50-$ 59, 9 per cent were between $60-69,7$ per cent were between $70-79$, and 3 per cent were aged 80 or older.

Of the 90 American interviewees, all self-identified as non-religious. 47 were male and 43 female; 6 per cent were in their late teens, 30 per cent were in their 20s, 23 per cent were in their 30 s, 16 per cent were in their 40s, 15 per cent were in their 50s, 8 per cent were in their 6os, and 3 per cent were in their 70s. Approximately 46 per cent of my informants were raised in California, with the rest being raised in the Midwest (10\%), East Coast (11\%), the South (11\%), the Southwest (3\%), the Pacific Northwest ( $3 \%)$ and about 10 per cent coming from other countries, such as England, Saudi Arabia, Ghana, and the Philippines. The percentages relating to where people were raised are approximations because sometimes people were raised in more than one state or country. In terms of educational attainment, approximately 6 per cent had only completed a high school education, approximately 29 per cent had either completed some courses at college or were currently enrolled in college, approximately 33 per cent had completed a bachelor's degree, and approximately 30 per cent had completed an advanced/graduate degree. As for racial/ethnic identifications, approximately 64 per cent of my sample self-identified as White or Caucasian, 12 per cent as Latino/a, Chicano/a, Hispanic, or Mexican-American, 12 per cent as mixed-race or 'other', 7 per cent as Asian, Asian-American, or Pacific Islander, and 3 per cent as Black or African-American (these are approximations because there were a few who classified themselves in atypical ways, such as 'Celtic,' 'Jewish', or 'Persian').

\section{Apostasy (the rejection of religion)}

One major difference between non-religious Americans and non-religious Scandinavians has to do with the process of individuals' loss of faith and the experience of their overall rejection of religion. Nearly all of those interviewed - both Americans and Scandinavians - were raised with some form of religion in their homes, and nearly all were religious as children, to varying degrees. And yet, while teenagers or adults, they left their religion behind. They came to no longer believe and no longer participate. They became, to use the formal term, apostates (Bromley 1988; Zuckerman 2011).

For Scandinavians, the experience of apostasy - 
the process of losing one's religion - was no big deal. It was a relatively minor, almost insignificant experience in their lives. In fact, religion was rarely something that they had outright 'rejected', but more like something that they had 'casually left behind'. That is, for most contemporary Danes and Swedes, losing their faith in God was just something that happened almost naturally as they grew older. Their rejection of religion was thus an almost matter-of-fact experience, about which they had little to say, and little to explain or recall. The majority of the Danes and Swedes that I interviewed said virtually the same thing: that at some point in their childhood, they had believed in God. They prayed. And almost everyone also said that his or her eventual loss of belief in God was simply a matter of growing up. Hardly anyone could ever recount some dramatic moment when his or her faith was shattered. Few could ever recall some specific event or instance that caused them to become a nonbeliever. Instead, what I heard-time after time-was that their belief in God simply withered with age, undramatically, and without much to-do.

For example, Tyge, a 62-year-old retired shop steward from Albertslund, had this to say concerning how he lost his childhood faith in God:
- It just happened.

- Was there a decisive factor in his transition to being a non-believer?

- Common sense.

Sigrid, a 53-year-old artist from Aalborg, said that she had believed in God as a child, but has considered herself an atheist all her adult life. I asked her when it was that she became an atheist, and she replied:

- When I grew up.

- Did something specific happen to her that led to a loss of faith?

- You get mature and think about things.

Neither Tyge nor Sigrid could or even cared to elaborate on their loss of faith, even when explicitly asked to do so. And the clear majority of Danes and Swedes interviewed exhibited a similar reticence on this matter.

In contrast, for most non-religious Americans, their apostasy was quite intense. It entailed a real personal struggle. It was a dramatic, life-changing experience that they recalled as being very significant and even painful. And unlike Scandinavians, Americans have a lot to say about it. They tend to talk about

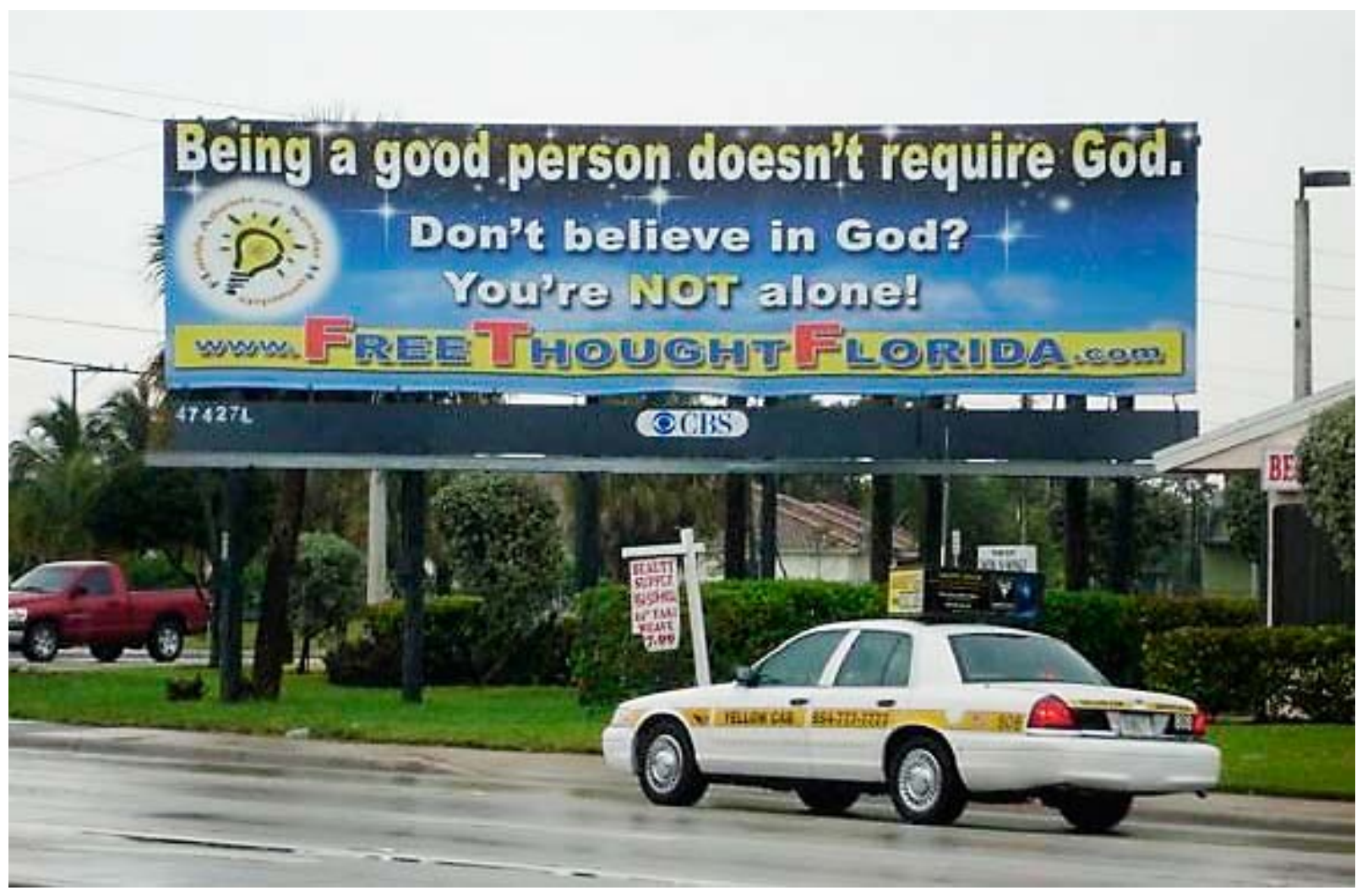

Atheist billboard in the USA. 
their loss of religious faith with great a high degree of personal reflection. They recall key events, specific causes, important details. A good example is Nathan, a 42-year-old African-American who was raised in Philadelphia, but now lives in Alabama, where he is a college professor:

I remember the day that I rejected Christianity ... one day I was driving to the gym to work out and I thought about a good buddy of mine who was in a wheelchair. He was a brilliant guy. I thought to myself: 'If Rick ever got up out of that wheelchair, it would be on CNN.... If a blind person got healed, it would be on CNN.' I watch CNN every day, and I've never seen a story about a paralysed person or blind person. ... So then I thought: God doesn't heal. ... Then I concluded that if God doesn't heal, then the God of the Bible does not exist. If the God of the Bible does not exist, then I don't believe in God. It was really that simple. ... I had to learn how to be a non-Christian. There was a lot of sort of angst in that. Here I am now, 26 years old, 27 ... and I've been pretty much a Christian all that time. A serious Christian. ... So I had to kind of learn this new worldview ... there was a lot of angst and frustration - but that didn't last long. ... I worship freedom now instead of God.

For another example, consider Beatrice, who lives in Seattle and is 39 years old. Beatrice was raised Catholic, but today, she identifies as an atheist. She can readily explain what started this transition:

When I was about 13 or 14 , my mom was diagnosed with breast cancer ... then, you know, within a year of that she passed away. So, I was 16 and my brother and sister like 14 and 13. I remember being very confused and very angry with God and not understanding how this could happen and how could ... you know, I talked to him like, 'What did I do wrong?' Why would God take her away from us? ... Why this painful kind of thing? I would say that's when my faith started to kind of ... I started to question my faith.... The day that she passed away, of course, our priest ... he came to talk to us and I remember specifically not buying in to what he was saying of like trying to answer our questions of why she died. He said something like, 'Well, she was in pain and now she's no longer in pain and she's in a better place' and this and that. I sort of just remember going, 'Ahh, I don't quite buy this.'

From Linda, aged 38, and a part-time journalist in San Diego:

So then I decide to go to Whitworth College. It is a Presbyterian school ... up in Washington $\ldots$ and I started to observe that, in general, not across the board, but - Christians were way more judgmental and annoying and narrowminded and tunnel-visioned and dull than nonChristians. And it just became very apparent to me that something's wrong here if this religion that professes to teach kindness and goodness and concern and care for others and generosity ... how come it is that the people who are not Christians are displaying those things more than the Christians who are supposed to abide in that belief system? So that started getting to me. It started bothering me. Then I would say, if I had to pinpoint a turning-point ... I was taking two classes side by side - one was a world religions class and one was a history of non-violence class. And I just learned so much. It's like, well, there's all these different religions, why and how and how dare Christians say we are it - the way, the truth, the light - we're the only way to go, everything else you're damned? I just ... suddenly that did not compute anymore. It just didn't compute. In the history of non-violence class, I think it was more than just Gandhi, but it was studying Gandhi that really shifted me. Because again, he's not a Christian, and look at the good in the world that he did and look at his values and how he treated people. I just could no longer say Christianity had the answers ... which was very scary to me to think along those lines... and it took me a long time, a l-o-n-g time to be able to comfortably think and accept and say that I am not a Christian. It took a l-o-n-g time.

Nathan, Beatrice, and Linda each had quite a lot more to say about their rejection of religion - but for the sake of space, I can't include their extended comments. And the three of them are quite typical of American apostates: they have a lot to say as they recount their rejection of religion. Thus, for most secular Americans, apostasy is a dramatic, significant experience, while for most secular Scandinavians, it is hardly memorable, and of little personal significance. 


\section{Opinions about religion}

A second noteworthy difference between Scandinavian seculars and American seculars is that the former generally have an indifferent or even mildly positive opinion of religion, while the latter tend to have a decidedly negative, critical opinion of religion.

When I asked secular Scandinavians about their opinions on religion, most had little to say and what they did say tended to be fairly benign. Even somewhat positive. While certainly not religious themselves, they still tend to think that religion is OK. Nice. Fine. Good. They think the church buildings are beautiful and peaceful, and they can appreciate them as venerable architectural symbols of their cultural and religious heritage. They think the church services at Christmas and Easter are cosy. They think that most pastors are kind, thoughtful, and decent men and women. They see religion - at least the Scandinavian Lutheran brand of religion - as basically a harmless, innocuous enterprise that even does a bit of good now and then. As for religious people who do believe in God? Well, that's fine for them. Below are some typical illustrations of this fairly nonjudgmental, non-critical orientation.

Rasmus is a 32-year-old chemical researcher at the University of Copenhagen. As he explained:

I don't believe in God ... but I've got nothing against religion. I think religion can be very comforting. It can be good for many people ... in some modest or reasonable way - I'm supporting that. I can't believe myself, but ... yeah. It's OK.

Trine is in her 40s, lives in Aarhus, and works as a trade journalist for the Danish dairy industry. She is a non-believer, but doesn't mind at all if others are:

I'm not repulsed by religion as such. It just doesn't have any meaning to me.

Lasse is a 25-year-old medical student from Angelholm:

I don't know anyone in Sweden, except my aunt, who believes in the Bible. And I know hundreds of people - hardly anyone believes the Bible. And maybe a bit more sort of believe in God. But most of my friends are atheists. Definitely - one hundred per cent. But they still respect those believing. And - you know - it doesn't matter that much.
Niels is a 79-year-old retired engineer from Copenhagen. When I asked him if he believed in God, he said no, but immediately qualified it by expressing his positive view of Christianity:

I don't believe that there is a man with a beard up there, but I think the Ten Commandments, they are a kind of nice rules for living ... how to treat other people.

Patrick is a 26-year-old submarine officer from Gothenburg. He does not believe in God, and yet has only nice things to say about religion:

I never got to believing in God or anything like that. Unfortunately, I wish I did because it might help me sometimes, but I never did. I don't find any religious bones in my body. But I do find church a real nice place to go.

Thus, for the majority of Danes and Swedes, religion simply isn't something that they cared to bother with, let alone criticise or condemn. Religion is like a tropical fish - nice, even cute, and certainly not threatening or worrisome.

In contrast, most non-religious Americans readily express much more negative, critical attitudes towards religion. For many of them, religion can be a bit of a problem. And they can tell you why. For some, religion harms the world by spreading false, delusional beliefs. For others, it has too much power in the political process, or it retards the educational system. And furthermore, religious people are misguided - or worse. Although certainly not all nonreligious Americans harbour such negative views of religion and religious people, many do. They are critical of specific religious beliefs which they regard as silly or deluded; they are critical of religious people whom they regard as misguided, hypocritical, or intolerant, and they tend to look back on the religion of their childhood in a decidedly negative light.

Donald is 37 years old and lives in southern California, where he works as an assistant librarian:

I don't respect religious believers. Pity might be too strong. But I do think ... 'boy, that's a very limited life and a very limited way to look at the world and it doesn't engender positive, you know, outcomes.' I think that's the biggest thing for me, is that Christianity tends to produce people who are xenophobic, who are ... just tight-assed [laughs], you know, to be 
sort of glib. Yeah, so I think that's where I'm at with that ... one thing that drives me nuts that religious people claim all the time is that you can't be good or you can't know what is good. Jim did this to me when we were at the church. He claimed that you 'cannot know good unless you know God'. I think it's exactly the opposite. That you cannot possibly be good if you're being good because you don't want to suffer the eternal punishment. I think that framework just fucks people up completely ... so how do I regard Christians now? I think mostly the way I regard them is with a little bit of anger that they could sort of misuse, in my estimation, the sort of fake authority that they claim. But beyond that, I think, to me there is a real sadness that I feel for people that are trapped in that because, for one thing because I was in that world so deeply. Now that I'm out of it, I see that I'm actually a much more loving, caring person and it's not love based on like, you know, some feigned concern about an immortal soul, but just like, hey we're all human beings ... that kind of sort of fellowship, brotherhood.

Aisha is 27 , of Bangladeshi origin, and lives in San Francisco. She is a graduate student, studying history. She was raised Muslim, but rejected it when she was 20. Today, she is an atheist, and her feelings about religion are, like Donald's, decidedly negative:

I realise that I'm getting into this whole antireligion thing. I don't know if my friends like this, but whenever I'm hanging out with them, I'm constantly talking about it ... how religion is hurting people, how people are so intolerant when they're so religious, and so on. I mean, I am pro-abortion, I'm pro-homosexuality, and I participate in the parades and everything. ... When people ask me, I tell them I'm atheist. I tell them why and things like that - there were just so many unanswered questions. I wouldn't understand why if there was a God, why there would be so much suffering among the most innocent and the most poorest people, you know? I must tell you when I let go of religion, one thing I felt was relief. I feel a profound sense of relief. I don't have any more unanswered questions. I know there's science to explain it and everything makes sense to me now. I can just live my life knowing I have control of my life. There is no afterlife. This is it, make the most

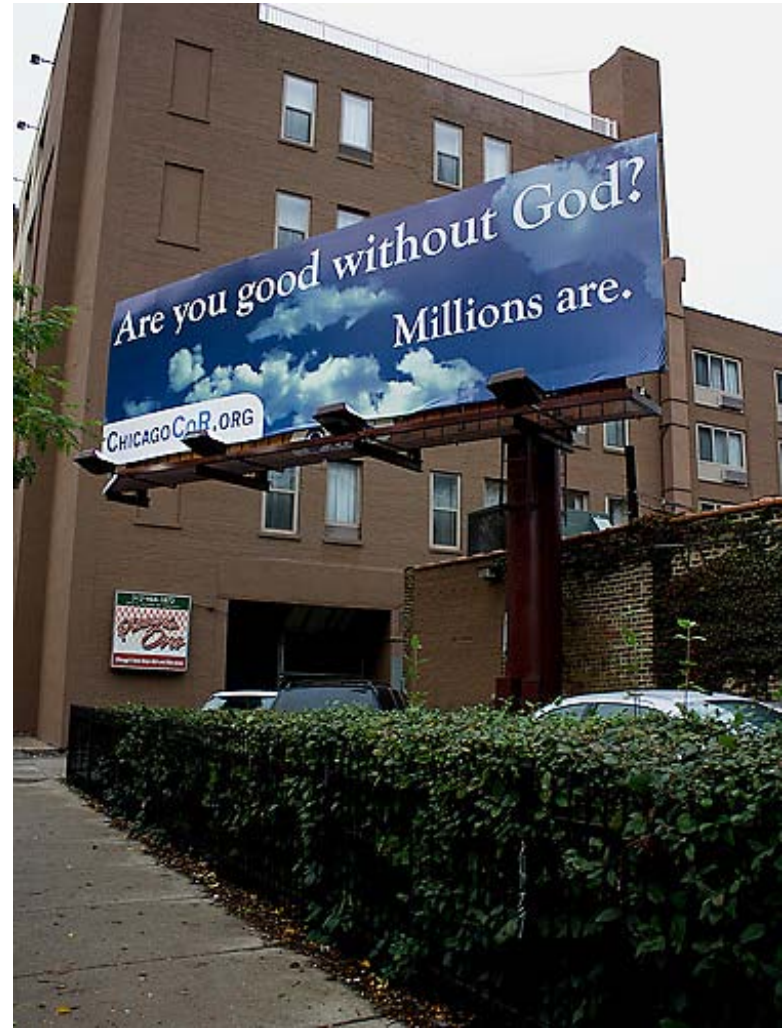

Atheist billboard in the USA.

of it and that's why I feel a great sense of relief. ... Yeah, and I also wanted to mention that ever since I've let go of religion, I think I've become so much more tolerant of different social groups.

I asked Aisha how she feels about other women who are believing Muslims:

Before I used to kind of just let it go and tolerate them and say it's their choice. But it's not their choice. Their family is brainwashing them, the religious community is brainwashing them.

Bill, aged 26, is in law school in New York. Here is how he talks about the period immediately after he stopped believing in Christianity:

- A lot of anger came out. It was just good to get all that out and have peace and to not be mad at religious people any more and to not feel the urge when I talk to someone who is religious to just shoot them down with my newfound logic and reason and to dismantle their faith. Because obviously they didn't have the answers, they hadn't thought through the things I had thought 
through so how easy would it be to bully them and to say that 'you're wrong' and make them really question things. I felt malicious in that, I had a lot of anger so I think it was good with my friend Barney just to get this stuff out for years.

- What were you angry about?

- I feel like I was lied to. I feel like I was too young to be making decisions that I feel like were made for me - I was mad at my parents, really mad at my mom for keeping me from ... who knows how different I would be today or who knows what path I would have gone down? I was just pretty pissed. ... I was, like, I've been taken, you know?

Jason, ageaged 26, from Texas finds himself having to defend his secularity a lot at work:

It's getting into stupid debates about God [laughs]. Because you can't fight with some people. You can't rationally say stuff about things. ... The worst people I have encountered, in my experience, the worst people I have encountered were these God-on-a-high-horse ideals or born-again Christians. There's three in particular that are all born-again. But they - I hate talking to them because there's no - you can't argue with them. ... I just want to strangle them sometimes ... like 'get it through your head!' The other thing is ... well, I work at a high school where 75 per cent are Hispanic and most of the population is Catholic there - and then teaching evolution. I always get very scared because I work in one of the biology classes ... and I always get very scared about what I can say and what I can't say about evolution. ... That's probably one of the worst parts, I feel like I have to tiptoe around people in our society that do believe in God because automatically if you don't believe in God ... then you must be a sinner. That may not be the case, but I feel that's how I'm perceived in some circumstances. So I feel like I have to tiptoe around!

From Nicole, aged 30, and a legal secretary in a small town outside of Los Angeles:

I see these fundamental Christians, the Mormons, these Muslims, I just ... I think how sad that they're so influenced by what people say and their convictions and they don't even think to question the simplest things. They take it lit- erally and, I mean, I find it really sad ... they're very sheltered, very suppressed and not seeing the world for its full potential ... and I feel liberated because I feel I have the truth now.

Sarah, aged 41, is from Ohio. She is in law school. She was raised a Jehovah's Witness, but is now an atheist:

Jehovah's Witnesses believe that demons are absolutely real ... they believe that Satan the devil is real ... they believe that the demons are real ... They believe that because there's no hell, they actually believe that these fallen angels, these demons ... which are the demon hoard of Satan the devil, reside here upon earth. That's a very important point. They believe that Satan the devil is the current ruler of this earth, of this physical earth, and that demons and Satan the devil reside here upon earth. That's important because that's basically their fountain of fear in terms of exerting control over the Jehovah's Witnesses. ... As a kid, I absolutely believed it. I absolutely believed it. ... So as a child - believing that there were demons all around me, that at any time could attack me, could hurt me, could play with my mind ... I lived in a world where there was a demon around every corner ready, willing and able to attack me. So that is horrifying. It's like living in, you know, a horror movie. It's like living in a war-zone. ... So it's pretty intense. ... I still get overwhelmed by fear still sometimes, especially in the middle of the night, and I will be absolutely terrified of demons.

For many secular Americans, religion is not like a tropical fish; it is not nice or cute or pleasant. Rather, it is more like a shark - something malevolent.

Thus, non-religious Americans are much more likely to be anti-religious than non-religious Scandinavians, as the above selections from various interviews illustrates.

\section{Agnosticism vs. atheism}

Most non-religious Scandinavians as well as most non-religious Americans would certainly not say 'yes' if asked if they believe in God. But whereas most secular Americans are much more likely to say 'no' to that question with a definitive surety, most secular Scandinavians would lean more towards a hesitant 'I don't know'. In other words, most secular Ameri- 
cans are more likely to be convinced atheists, whereas most secular Scandinavians are more likely to be lukewarm agnostics (Riis 1994).

A significant proportion of Scandinavians consider themselves to be secular - in fact, approximately 50 per cent of Swedes described themselves as such (Lüchau 2010, Ahlin 2005). And yet, non-religious Scandinavians are generally skeptical of the actual designation 'atheist' (Warmind 2005). They see it as too convinced, too sure, too strong, too angry. As one Danish man, Jeppe, aged 72 , said to me, 'an atheist is a professional hater of God'. Jeppe does not believe in God himself, and yet he doesn't like 'atheists', and he wouldn't identify himself as one.

Furthermore, most Scandinavians who don't necessarily believe in God, are also simultaneously uncomfortable denying the possibility of God outright. After all, one can't be sure, right? The most common type of response that I got during my interviews from Scandinavians - when I directly asked people about their belief in God - was a sort of agnosticism by default, or agnosticism as an afterthought. That is, while most non-religious Scandinavians baulk at the God question - they definitely won't say 'yes', but they also won't offer a definitive 'no'.

When I asked Morten, a Dane from Aarhus, aged 55, is he believes in God, he replied:

Uh-h-h ... I don't know. I don't know if ... well ... I haven't had ... I don't think I have experi- enced God, especially. But at the other hand, I have also ... if everything is just a matter of-if everything is just by chance, well, then, there may be something. But I don't know what it is and I haven't an idea of what would be.

From Pia, from Stockholm, aged 33, and her belief in God:

- That's a difficult question. [laughter] I don't know, I don't know.

- When you were young, did you believe in

God, or were you always like this?

- I think I was always like this.

- Just not quite sure?

- Yeah [nervous laugh].

From Kirsten, aged 46, from Køge, a vice-principal at a public school, concerning God:

I don't really think so much about it. So I wouldn't know right now how to define it. But I believe in something. ... Well ... there's more between heaven and earth ... you know? And there's more than I can understand, but I don't think it's a big father sitting up in the sky watching us and helping us, or whatever. But there's something ... maybe ... I don't know.

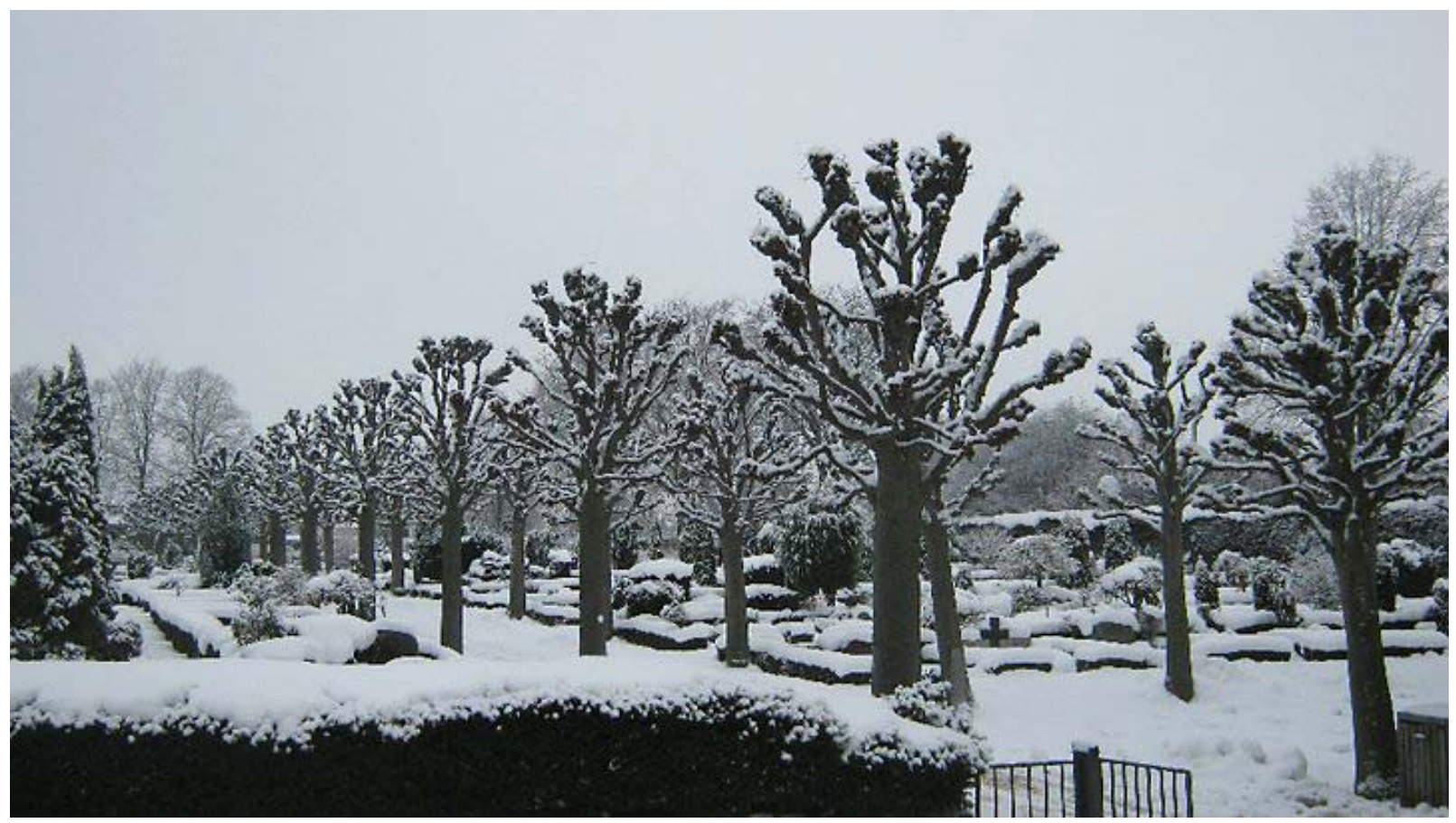

Graveyard in Aarhus, Denmark. 
From Sven, a 69-year-old doctor from Malmö. Does he believe in God?

$\mathrm{Oh}$, that is a difficult question, because you must make a definition what is God, and the God as it is described in the Christian church, I have very difficulties to believe that ... I mean, you can say that there's a big bang, where the whole thing started, okay, I can understand. But it's difficult to really grasp what happened. Then what was before big bang? And what created the big bang? And I don't know, I have no answer for that and science cannot give me an answer ... I must admit that there are some things I don't know and cannot understand ... an atheist is a person that denies God, and I ... I cannot say that I deny God, because I cannot say I'm sure that there was not a God. So I would say I'm quite indifferent on this position.

From Peter, a 21-year-old Swedish medical student, living in Odense:

I'm into science and I believe that everything is created by science - so that God created the world in seven days and stuff like that, I don't believe in that. But I believe there is something that maybe controls our minds or something, but I can't put my finger on it and say what it is ... but probably something.

From Iben, a 47-year-old programme manager at a telecommunications company in Aarhus. Does she believe in God?

- I believe in something bigger than me, but I don't know what it is.

- But if you had to check a box 'do you believe in God?' - would you choose yes or no or what would you check?

- The third one ... I don't know. [laughter]

From Ingrid, a 39-year-old chemical engineer from Stockholm:

I wouldn't say I'm religious. I'm probably a bit like most Swedish people, I hope that there is something, but it doesn't really interest me. And I really don't think there is something, but every time I say that I don't think there is something, I always feel a bit bad about it because what if there is and then I lied and you'll be mad at me. [laughter]
As the above interview excerpts indicate, many secular Scandinavians are reluctant to define themselves as atheists and to outright deny the possibility of God existing. Many prefer to say that they just don't know, or that opinions about the existence of God must remain uncertain, or that perhaps there is 'something' out there between heaven and earth, but who can say? This stated belief in 'something' rather than God, per se, has also been found in the research of Ina Rosen (2009). And according to Hans Raun Iversen ${ }^{1}$, a common Danish orientation concerning God is perhaps something best characterised as 'agnostic deism'. Of course, I did interview a few convinced atheists in Denmark and Sweden, but they were in a distinct minority.

In contrast, many secular Americans are much more likely to express an atheist position and even self-label themselves as atheists. Consider Henry, who is 41 , and a computer programmer from Orange County. How does he define himself?

Explicit, outspoken atheist ... and I understand what the word means. I'm not afraid of the word and it perfectly describes what I'm not, which is a believer in any God or gods ... I remember at one point saying 'I'm an atheist and I don't believe this' and I rejected it. I actually felt good about everything because I remember thinking that scientific stuff made a lot more sense without religion being a constant conflict. It was really quick for me.

From Greg a newspaper editor, aged 33, from Ohio:

I'm definitely an atheist. I'm just now, I suppose, getting over the bitter ex-Christian ... I'm just kind of happy being an atheist ... Yeah, I've gotten past the being angry at anyone who wants to proselytise now. I take a little more sympathetic approach. For a while there I was extremely angry at anyone who would attempt to convince me that I had gone wrong at some point.

From Rita, aged 30, and a secretary in Los Angeles:

I'm an atheist. A strong atheist. I don't believe in any kind of supernatural anything. ... I think that there's coincidences that happen.... Every once in a while something will be skewed or whatever - like, weird things happen - people

1 From email correspondence on 13 October 2011. 


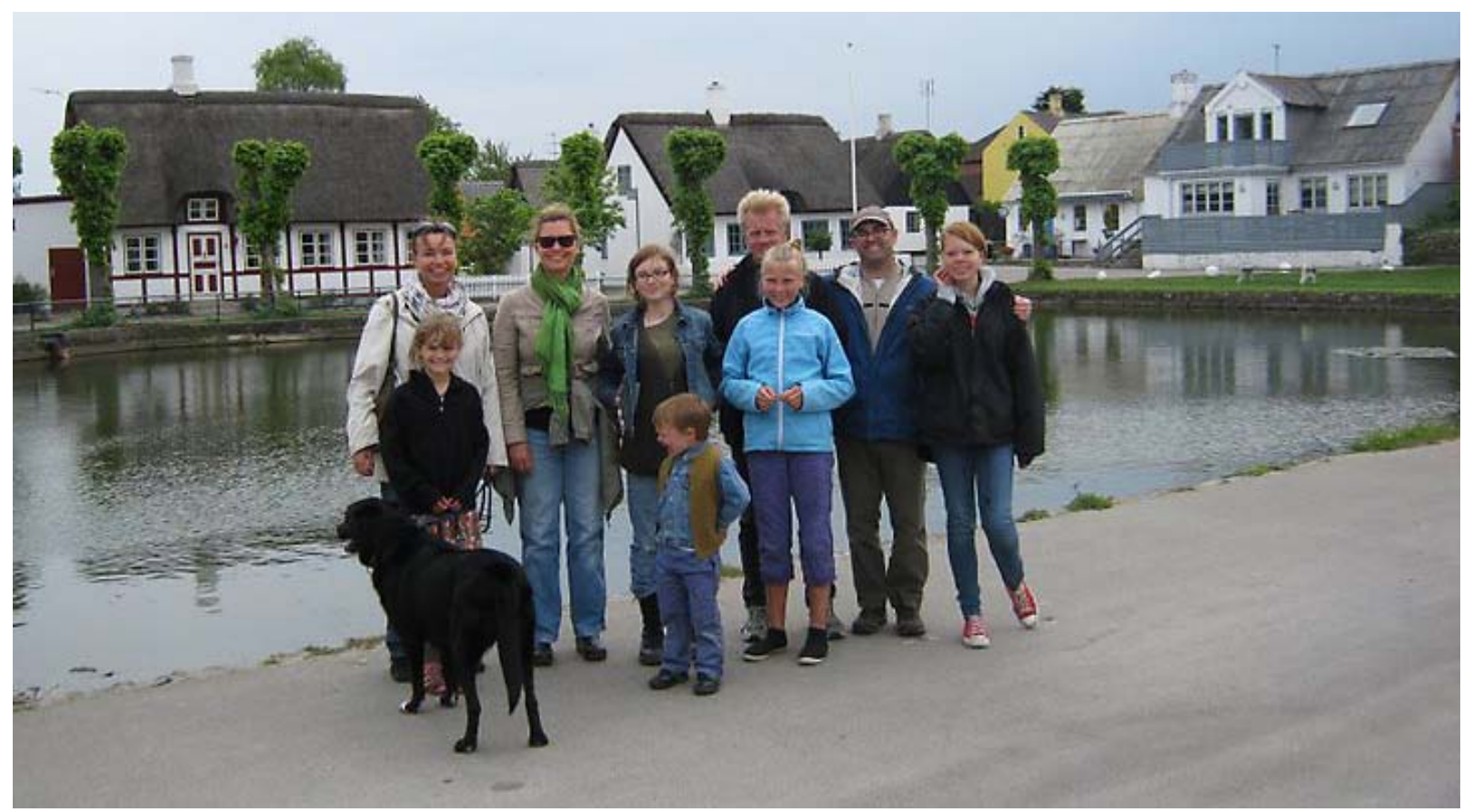

Phil with family and friends, Samsø, Denmark.

get sick all of a sudden for no reason that were normally healthy. People get well all of a sudden that were normally really sick. I just think that things just happen sometimes and maybe we don't know why, but it's not anything to do with God or Jesus or anything like that.

From Ian, aged 45, an anthropology professor from Maryland:

I would check the atheist box with only a glimmer of reluctance, maybe. I mean, I spent a while calling myself agnostic just because I thought to say you were atheist was hubristic. But now I pretty happily say that I'm atheist.

From Tammy, aged 53, an IT employee from Los Angeles:

I'm definitely an atheist. I mean, I'm a scientist. I've got my degree in biology. I've got my Master's degrees in information systems and in psychology. So the basis for my understanding of things is reason. I just ... it wasn't reasonable to think that an omniscient, omnipotent power would create such a flawed universe.

From Azamat, aged 23, in college in Texas:
I am definitely passionate about being an atheist. ... Actually, I don't refer to 'God' anymore. ... I refer to it as 'Your shit god.' When I'm talking to somebody. 'Your shit god.' Because it's not my god. It's their god. So, your. And he's not a good god. You always hear an adjective that describes god as like 'great' or 'almighty'. No. I want to use an adjective that represents how I really feel about the subject, which is 'Your shit god.'

From Stacy, aged 31, a legal assistant from Portland:

I don't believe in God and I have absolutely no faith whatsoever and I'm convinced by science. ... I would definitely describe myself as an atheist .... and no one will be able to convince me otherwise unless a light from above comes down and speaks directly in my face and tells me how it is. Because who's for sure? How do they know? Like, no one knows what happens after you die, so no one has the right to tell me ... because they've never died and come back. But I would describe myself as an atheist, a nonbeliever.

As the above interview excerpts reveal, the very 'flavour' of American secularity is quite different from that found in Scandinavia. First, non-religious 
Americans are much more articulate about their rejection of religion, and see it as a major transition in their lives, whereas most non-religious Scandinavians don't give it much thought, and see their loss of faith a something fairly mundane. Secondly, most non-religious Americans are much more critical of religion - and religious people - whereas most nonreligious Scandinavians exhibit a much more laid back, non-judgmental, and even sometimes positive view of religion and religious people. And finally, many non-religious Americans are much more likely to express a convinced atheistic orientation, and even self-label as atheists, whereas many non-religious Scandinavians are much more likely to express a non-committal, open-minded agnostic orientation.

\section{Conclusion: accounting for the differences}

But how might we account for and explain these differences? Surely there is no single, obvious answer. Widespread or common attitudes, opinions, and worldviews within specific cultures never have simple or solitary explanations, and their sources are inevitably multiple, varied, historical, and often unknowable. But, while acknowledging just how hard it is to accurately explain people's attitudes and beliefs,
I will not avoid an attempt. I conclude this paper by hazarding some possibilities.

First off, nearly all of the above differences between secular Americans and secular Scandinavians can be partly explained by the fact that religion is much more widespread and pervasive in the USA than it is in Scandinavia. In the United States, religion is constantly broadcast on the television and radio; politicians wear their religion on their sleeves, fundamentalism is alive and well, Biblical literalism is prevalent, sports events begin with prayers, children must recite a prayer-like declaration which includes a reference to God every morning in every public school, the military is heavily Christianised, and so on. Faith in God and church attendance are far higher in the USA than in nearly all other Western democracies (Inglehart et al. 2004, Putnam \& Campbell 2010, Berger et al. 2008). In stark contrast, religion is relatively weak, subdued, and marginal in Scandinavia (Zuckerman 2009, 2008). Hans Raun Iversen (2006) specifically designates Danes and Swedes as 'the most secular people in the world'. Many others agree (for example, Jenkins 2011, Palm \& Trost 2000). According to a 2005 Eurobarometer survey, only 31 per cent of Danes and 23 per cent of Swedes said they believe there is a God. Indeed, Denmark and Sweden have the lowest rates of church attendance in the world, the lowest rates of acceptance of standard Christian beliefs such as the literal resurrection of Jesus or the existence of heaven and hell (see Lüchau 2010, Bondeson 2003, Inglehart et al. 2004), religious fundamentalists are few and far between, religion is not trumpeted or championed by politicians, and faith in God tends to be a very personal, very quiet thing - not something made public. Thus, I would argue that because religion is so widespread and public in the United States, while it is so weak and personal in Scandinavia, this helps account for the different flavours of secularity we find in each society.

Eurobarometer poll from 2005. 
When religion is widespread in a given culture, as it is in the USA, rejecting religion (apostasy) will be a much bigger deal than when religion is weak. When religion is pervasive in a given culture, as it is in the USA, those who are not religious are apt to be more defensive, and hence more judgmental and critical - whereas if religion is marginal, as it is in Scandinavia, then those who are not religious can ignore it. They can even find it nice, if not a bit quaint. Thus, secularity can have a reactive manifestation as well as a non-reactive or passive manifestation. American secularity is much more reactive, and hence stronger, more oppositional, more atheistic, and more negative in its flavour. Scandinavian secularity is non-reactive, and hence fairly gentle, agnostic, and mundane. American secularity is often against religion, while Scandinavian secularity just is. As Hans Raun Iversen (2006) argues, in contemporary Denmark there is no real social pressure to be religious, and thus no real reason to be against religion. Again, the situation is very different in the USA, where there is often extensive social pressure to be religious. American seculars are therefore still in large part dancing with religion even as they reject or critique it. They are still dealing with it, and so their secularity is much sharper, more defined, and indeed, harder. In contrast, Scandinavia seculars aren't really dancing with religion, because religion itself isn't dancing much, or demanding their attention. It is rather sitting on the side of the dancefloor, sipping punch, and talking to the old ladies. Thus, Scandinavians are doing other things. They're not obsessing about religion, or worrying about it, or critiquing it. Scandinavian secularity is thus much more benign, and fairly soft in style and tone. Scandinavians are not anti-religious, but rather, in the analysis of Peter Lüchau (2010) mentioned earlier, they are simply 'a-religious'.

Related to the above is the fact that religion has much more power in American society than in Scandinavian society. For example, in the United States, religious people actively work to limit women's reproductive rights and to restrict the rights of homosexuals in America. Religious people actively fight to limit the teaching of evolution in public schools. Religious people are also actively involved in government at all levels, from local city councils up to the White House. Lobbyists for religion are strong and numerous. Additionally, religion is directly equated with morality in the United States, and thus non-religious individuals are stereotyped as being amoral or immoral; surveys report that atheists are the least-liked minority group in America (Edgell et al. 2006). None of these facts holds true in Scandinavia, where religion has very little political sway; non-religious people are not maligned or mistrusted, and the church is not at the pervasive centre of most people's social lives (Iversen 1997). Given these different socio-cultural realities, it makes sense that non-religious people in the USA will be much more defensive and critical about religion than their counterparts in Scandinavia (Bagg \& Voas 2010).

Another factor helps account for the differences in secularity found in the United States and Scandinavia, has to do with differing general cultural styles specifically, the cultural propensity to be more open, confident, and forceful about one's opinions in the United States, compared to the cultural propensity to be less open, more humble, and less aggressive about one's opinions in Scandinavia. While these are of course gross generalizations, bordering on stereotypes, I do believe that Americans, on average, are socialised to be more confident about their opinions, and to share them with force and surety, whereas I believe that Scandinavians, on average, are socialized to not 'stick out' too much, to not act as if they 'know everything' - in short, to avoid being boorish or loud-mouthed. While there are always exceptions, most Scandinavians are simply more reserved and reticent than most Americans. Åke Daun (2004) confirms my observations, noting the tendency towards taciturnity among Scandinavians, especially Swedes. These generalised differences in cultural mentalities or social styles helps to explain, at least in part, why most secular Americans have more to say about religion, are apt to be more critical of it, and can be more long-winded on the matter than their Scandinavian counterparts.

More possibilities certainly exist. But the main goal of this paper has simply been to argue that atheism and secularity come in a variety of styles, tones, and orientations - and this variety is surely linked to the social-cultural environment in which atheism and secularity manifest themselves.

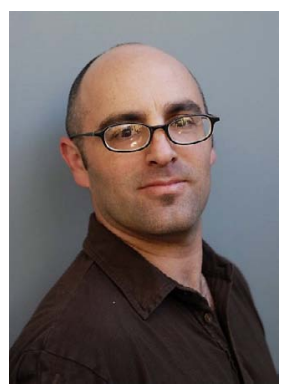

Phil Zuckerman, $\mathrm{PhD}$, is professor of sociology and secular studies at Pitzer College in Claremont, California. He studies contemporary secularity, and he is the author of Faith No More (Oxford, 2011), Society Without God (NYU, 2008), and the editor of Atheism and Secularity (2 volumes, Praeger, 2010). Email: phil_zuckerman(at)pitzer.edu. 


\section{References}

Ahlin, Lars 2005. Pilgrim, turist, eller flykting? En studie av individuell religiös Rörlighet $i$ sen-moderniteten, Stockholm: Brutus Östlings Bokförlag Symposium.

Bagg, Samuel \& David Voas 2010. 'The Triumph of Indifference: Irreligion in British Society.' In: Phil Zuckerman (ed.), Atheism and Secularity, vol. 2. 91-111. Santa Barbara, CA: Praeger.

Berger, Peter, Grace Davie \& Effie Fokas 2008. Religious America, Secular Europe? A Theme and Variations. Aldershot: Ashgate.

Bondeson, Ulla 2003. Nordic Moral Climates. New Brunswick, NJ: Transaction Publishers.

Bromley, David 1988. Falling From the Faith: Causes and Consequences of Religious Apostasy. Beverly Hills, CA: Sage.

Campbell, Colin 1971. Toward a Sociology of Irreligion. New York: Herder and Herder.

Daun, Åke 2004. Swedish Mentality. University Park, PA: Pennsylvania State University Press.

Demerath, N. J. 2001. Crossing the Gods: World Religions and Worldly Politics. New Brunswick: Rutgers University Press.

Edgell, Penny, Joseph Gerteis \& Douglas Hartmann 2006. 'Atheists as "Other": Moral Boundaries and Cultural Membership in American Society’. American Sociological Review 71 (2): 211-34.

Inglehart, Ronald, Miguel Basanez, Jaime Deiz-Medrano, Loek Halman \& Ruud Luijkx 2004. Human Beliefs and Values: A Cross-Cultural Sourcebook Based on the 1999-2002 Values Surveys. Mexico City: Siglo Veintiuno.

Iversen, Hans Raun 1997. 'Leaving the Distant Church: The Danish Experience.' In: Mordechai Bar-Lev \& William Shaffir (eds), Leaving Religion and Religious Life. 139-58. Greenwich, Connecticut: JAI Press.

-2006. 'Secular Religion and Religious Secularism: A Profile of Religious Development in Denmark since 1968.' Nordic Journal of Religion and Society 19 (2): 75-92.

Jenkins, Richard 2011. Being Danish: Paradoxes of Identity in Everyday Life. Copenhagen: Museum Tusculanum Press.

Kosmin, Barry A. 2007. 'Contemporary Secularity and Secularism. In: Barry Kosmin \& Ariela Keysar (eds), Secularism and Secularity: Contemporary International Perspectives. 1-13. Hartford, CT: ISSSC.

Lim, Chaeyoon, Carol Ann McGregor \& Robert Putnam 2010. 'Secular and Liminal: Discovering Heterogeneity Among Religious Nones.' Journal for the Scientific Study of Religion 49 (4): 596-618.

Lüchau, Peter 2010. 'Atheism and Secularity: The Scandinavian Paradox.' In: Phil Zuckerman (ed.), Atheism and Secularity, vol. 2. 177-96. Santa Barbara, CA: Praeger.

Palm, Irving \& Jan Trost 200o. 'Family and Religion in Sweden.' In: Sharon K. Houseknecht \& Jerry Pankhurst (eds), Family, Religion, and Social Change in Diverse Societies. 107-20. New York: Oxford University Press.

Pasquale, Frank 2006. 'Varieties of Irreligious Experience in the American Northwest.' Paper presented at the annual meeting of the Society for the Scientific Study of Religion, Portland, Oregon 19-22 October.

Pasquale, Frank, Luke Galen \& Phil Zuckerman 2013. Being Secular. New York: Oxford University Press.

Pruyser, Paul W. 1974. 'Problems of Definition and Conception in the Psychological Study of Religious Unbelief.' In: Allan W. Eister (ed.), Changing Perspectives in the Scientific Study of Religion. 185-200. New York: John Wiley \& Sons.

Putnam, Robert \& David Campbell 2010. American Grace: How Religion Divides and Unites Us. New York: Simon and Schuster.

Riis, Ole 1994. 'Patterns of Secularization in Scandinavia.' In: Thorleif Pettersson \& Ole Riis (eds) Scandinavian Values: Religion and Morality in the Nordic Countries. 99-128. Uppsala: Acta Universitatis Upsaliensis.

Rosen, Ina 2009. I'm a Believer - But I'll be Damned if I'm Religious. Lund Studies in Sociology of Religion, vol. 8. Lund: University of Lund.

Storm, Ingrid 2009. 'Halfway to Heaven: Four Types of Fuzzy Fidelity in Europe.' Journal for the Scientific Study of Religion 48 (4): 702-18.

Voas, David 2008. 'The Rise and Fall of Fuzzy Fidelity in Europe.' European Sociological Review 25 (2): 155-68.

Warmind, Morten 2005. 'Ateisme i Danmark.' In: Morton Thomsen Højsgaard \& Hans Raun Iversen (eds), Gudstro i Danmark. 279-92. Copenhagen: ANIS.

Zuckerman, Phil 2008. Society Without God: What the Least Religious Nations Can Tell Us about Contentment. New York: New York University Press.

-2009. 'Why are Danes and Swedes so Irreligious?' Nordic Journal of Religion and Society 22 (1): 55-69.

-2011. Faith No More: Why People Reject Religion. New York, NY: Oxford. 